\title{
Developments In the Law of Trademarks and Service Marks-- Contributions of the Common Law, The Federal Act, State Statutes and the Restatement of Torts
}

\author{
James M. Treece
}

The development of common law protection of trade symbols has resulted in different treatment of symbols which are affixed to products and those which are not. Non-affixed marks-those used primarily by firms providing services-must be used for a longer period of time than marks which are affixed to products. Professor Treece examines the development of the difference in treatment and concludes that a rule protecting all trade symbols as of the time they are first used in the market to communicate in any manner with consumers would be more appropriate. Unsatisfied with the steps toward first use protection that have thus far occurred under the Federal Trademark Act of 1946, he suggests a more flexible interpretive approach by the courts and administrative agencies or, more preferably, congressional amendment. Professor Treece then assesses the contribution of the tentative draft of the Restatement (Second) of Torts to a rule of first use protection.

The Englislı common law courts first protected consumers against a mercliant's false use of a well known trademark to pass off goods from an unknown source by giving a cause of action, for passing off, to the tradesman whose mark the fraudulent seller misused. It soon became apparent, however, that the public interest in orderly markets could be further served if tradesmen were enabled to protect the trade symbols by which the public recognized a firm as a source of products or services even before the symbols became well known. Accordingly, the English courts evolved a system of law for securing to firms exclusive rights to potential source symbols as of the moment when the symbol was first used. Initial cases involved products as opposed to services and the courts selected affixation of the symbol to the product as the moment of first use.

* Professor of Law, University of Texas. B.S. 1959, M.A. 1962, J.D. 1961, University of Illinois. 
The initial experiments worked satisfactorily and the propriety of securing protection for a firm's potential source symbols at an early date remained unchallenged. The natural development would have been to recognize events in addition to affixation to a product as signalling the commencement of exclusive rights in designations that had potential as symbols of source to consumers. Such developments would have served firms selling services especially well and would have further served product firms. For a number of reasons, however, the expected advance did not occur at the expected time, and service firms, were, and in some instances, still are, deprived of the security in their choices of source symbols that was afforded product firms by the affixation rule. This Article first examines the development of, and the reasons for, the discrimination in trade symbol law against the marks of service firms and the reluctance of courts and legislatures to recognize events other than affixation as securing rights in the marks of product firms. Parts II and III then undertake a critical analysis of the current state of trade symbol protection and conclude that an arbitrary symbol should receive legal protection from the moment a firm first uses it in any way as a source symbol.

TRADE SYMBOL PROTECTION AT COMMON LAW

\section{A. Development}

Pre-Renaissance England had a relatively sophisticated market economy. In the twelfth and thirteenth centuries, trade took place at annual fairs and weekly markets where sellers of like goods occupied contiguous stalls thus enabling consumers to compare similar goods easily before purchasing. Artisans usually manufactured what they sold and sold directly to the ultimate user. Middle men rarely appeared in the marketing process, and there was little need for the inaker of goods to package them, decorate them, or mark them with a distinctive device symbolizing origin. Typically, the seller's face or the location of his place of business served as his identifying syınbol. Nevertheless, merchants did use trade symbols to mark their packages. Moreover, the goods within the packages often carried a gnild mark or a production inark or both. . Merchant's marks, at least in most cases, signified not the craftsman who made the product but the merchant who trafficked it. They were used primarily to enable illiterate warehousemen to carry out shipping orders and to identify goods in the event of robbery or shipwreck. The guild mark, when affixed to the product, identified the guild but not the individual artisan. The individual craftsman's production mark functioned primarily as a guide to 
guild officers in tracing defective wares to the offending craftsinan. ${ }^{1}$

As wares from other places began to appear in local markets, soine merchants' marks, guild marks, and production marks became known to consuiners as syinbols of quality, and competitors soinetimes made attempts to sell their goods under another's well-known mark. ${ }^{2}$ Both the guilds and the courts regulated false marketing, mcludingafter marks became important indicators of source-falsely marketing goods under another's mark.

The first "reported" coinmon law case appears in the reporters' notes on the case of Southern v. How. ${ }^{3}$ Judge Doderidge, during the argument of the Southern case, recalled a case decided about 1580 which mvolved the marketing of cloth. The plaintiff had alleged that he made good cloth; that he customarily set his inark to his cloth; that people knew his reputation for good cloth, recognized his mark, and relied upon the mark to identify his cloth; and that defendant had deceitfully placed a copy of plaintiff's famous mark on defendant's poorly made cloth and, one infers, thereby made sales that otherwise plaintiff would have made. Doderidge said that the court had resolved "that the action did well he." ${ }^{4}$ Thereafter a typical statement by a lawyer was: "the law has been settled from the yearbooks downwards, that a man has no right to trade under false colours, and to sell his goods as another's."

Because the defendant in the clothier's case accoinplished his fraud by duplicating his rival's trademark, the case seems to give tradesmen a cause of action for mere copying. Later cases show, however, that the decision in the clothier's case turned on the copier's fraudulent

1. F. Schechter, The historical Foundations of the Law Relating to TRADEMARKS 47-63 (1925).

2. Jones, Historical Development of the Law of Business Competition, 36 YALE L.J. 351, 369 (1927); Paster, Trademarks-Their Early History, 59 TRADEMARK REP. 551 (1969).

3. 79 Eng. Rep. 1243 (K.B. 1617). The five reports of Doderidge's dictum in Southern v. How conflict on whether Doderidge said the injured purchaser of cloth or the wronged clothier maintained the remembered action. Croke, in his report, for instance, listed Doderidge as saying that "an action upon the case was brought by hin who bought the cloth . . . and adjudged maintainable." 79 Eng. Rep. 400, 402 (K.B. 1617). Schechter divells at length on the various reports of Doderidge's dictum in Southern v. How, cautioning that whatever Doderidge said, the remarks remain dictum. F. Schechter, supra note 1, at 6-13. Professor Morrison asserts that the almost universally overlooked case of Dean v. Steel, 82 Eng. Rep. 339 (K.B. 1626), where a similar Doderidge dictum occurs, shows that Doderidge reported that the wronged clothier brought the action himself. Morrison, Unfair Competition and Passing Off, 2 SYDNEY L. REv. 50, 54 (1956). See also the discussion of the several reports of Southern v. How by Creswell, J., in Crayshaw v. Thompson, 134 Eng. Rep. 146, 147 (C.P. 1842).

4. 79 Eng. Rep. at 1244.

5. Knott v. Morgan, 48 Eng. Rep. 610, 612 (Rolls Ct. 1836). 
intent and the deception of consumers-passing off-and not on the ineans of accoinplishing it-copying the trade inark. For example, in Blanchard $v$. Hill ${ }^{6}$ plaintiff souglit an injunction against defendant's use of the Great Mogul as a trademark for playing cards, alleging that plaintiff had an exclusive right to that inark under an old Royal Charter. Lord Chancellor Hardwicke said that he knew of no case enjoining a trader from using a inark being used by another. The clothier's case differed from the one at bar, continued the Chancellor, for there the defendant did not merely use the mark, but used it with the fraudulent intent either to sell bad cloth or to draw away plaintiff's customers. Passing off, not copying alone, constituted the wrong. The petition in the Blanchard case was further defective in not alleging harm to petitioner or consumers caused by defendant's use. A petitioner fared similarly a century later in Perry $v$. Truefitt. ${ }^{7}$ Perry alleged that he sold "Perry's Medicated Mexican Balm," a vegetable fat hair dressing, and sought to enjoin Truefitt from selling "Truefitt's Medicated Mexican Balm," a hair dressing made, according to Perry's affidavits, fron animal fats. Perry, bettering the playing card manufacturer in Blanchard, raised the possibility that Truefitt in his marketing efforts intentionally misrepresented to consumers the nature of his product. Nevertheless, Lord Langdale denied the plaintiff's petition, probably because Truefitt's narketing inethod did not deceive consumers about source.

When the two requirenents of passing off-intent to deceive and successful deception-were found, the courts awarded damages or granted injunctions against using another's trademark. In Morrison $v$. Salmond ${ }^{8}$ the successful plaintiff proved not only that defendant had imitated plaintiff by selling "Morrison's Universal Medicines," but that defendant had intentionally sold its product as plaintiff's. The court ruled that defendant could not thus use plaintiff's tradeinark to pass off. In Knott v. Morgan ${ }^{9}$ the court enjoined the defendant from painting and decorating its busses to look like plaintiff's and froin using plaintiff's tradename on the sides and backs of defendant's busses. The court said the defendant had copied plaintiff's trade dress and used plaintiff's trade name intending to attract customers under the false pretense that defendant's busses were plaintiff's. ${ }^{10}$

In some cases the courts were apparently willing to protect a mark

6. 26 Eng. Rep. 692 (Ch. 1742). See also Webster v. Webster, 36 Eng. Rep. 949 (Ch. 1791).

7. 49 Eng. Rep. 749 (Rolls Ct. 1842).

8. 133 Eng. Rep. 795 (C.P. 1841).

9. 48 Eng. Rep. 610 (Rolls Ct. 1836).

10. Id. at 612. Day v. Binning, 47 Eng. Rep. 611 (V.C.C. 1831). 
even though, technically, the two requirements of passing off were not found. Thus, if plaintiff's mark was extremely well known, an injunction issued even if the defendant "intended" no harm, but copied the mark "innocently." 11 Similarly, proof that defendant adopted a symbol similar to one used by plaintiff intending to pass off his products or services as plaintiff's went far toward convincing a court that enough of the public associated the symbol with plaintiff to support the issuance of an injunction against passing off. ${ }^{12}$ There were also traditional cases in which the courts refused to find a passing off, even if plaintiff's symbol was well known, if defendant's total marketing effort sufficiently informed consumers that the tendered products or services came from a source other than plaintiff. ${ }^{13}$

Thus during the nearly 300 years that the courts applied the principle of the clothier's case, slight and sporadic modifications began to occur. The next logical step was the protection of trade marks and service marks in their own right irrespective of the theory of passing off.

This step was finally taken in $M^{\prime}$ Andrew $v$. Bassett, ${ }^{14}$ a case involving a relatively innocent defendant who simulated plaintiff's relatively unknown trademark. Plaintiff in M'Andrew had begun manufacturing liquorice in July 1861, some of which was sold in August 1861, stamped with the mark "Anatolia." In September 1861, defendant, who also manufactured liquorice, received an order for five and one-half hundredweight of hquorice accompanied by specific instructions to stamp it "Anatoha." A sample of plaintiff's liquorice accompamied the order. The defendant filled the order as specified. When plaintiff sought to enjoin further use of the mark "Anatolia" on liquorice, defendant argued that plaintiff could not have acquired a protectable legal interest in the term "Anatolia" in the short period between the end of July and the middle of September. In substance, defendant argued that a court could not protect a tradesman against another's use of his mark unless the plaintiff had used his mark sufficiently to give it a "general notoriety and reputation in the market"15an allegation not made with respect to "Anatoha." Lord Westbury ruled that plaintiff could prevail without alleging that "Anatolia" had a general notoriety and reputation in the inarket if he alleged: that the term "Anatolia" did not misdescribe his product; that plaintiff actually had used the term "Anatolia" on a vendible article in the market

11. Millington v. Fox, 40 Eng. Rep. 956 (Ch. 1838).

12. See Howard v. Henriques, 5 N.Y. Super. (3 Sandf.) 725 (1851).

13. Corwin v. Daly, 20 N.Y. Super. (7 Bosw.) 222 (1860) (defendant, like plaintiff, used the term "Club House" on gin labels which in most other respects differed from plaintiff's labels).

14. 46 Eng. Rep. 965 (Ch. 1864).

15. Id. at 967 (emphasis added). 
place; and that defendant, knowing of plaintiff's prior use, imitated the mark for the purpose of selling articles under it. ${ }^{16}$

Although Lord Westbury based his decision partially on defendant's knowledge of plaintiff's prior use of "Anatoha," thus suggesting a theory of passing off, he clearly advanced the law beyond the teaching of the clothier's case by diminishing the importance of the mark's notoriety. Moreover, the injunction granted agamst defendants did not speak merely to passing off but instead forbade defendant perpetually from marking upon any liquorice the word "Anatolia" or from selling or otherwise disposing of any liquorice marked or stamped "Anatolia" other than plaintiff's.

Dictum in the earlier case of Hall v. Barrows ${ }^{17}$ offered support and a rationale for this result. The Hall opinion suggested that a right in a trademark, enforceable in the courts, should accrue from the moment of its first use on a product in the marketplace. ${ }^{18}$ The Hall court advanced two reasons for recognizing rights in marks as of this time. First, courts have difficulty discovering the point in time when sufficient prominence attaches to the mark to justify protecting the mark user against passing off and, therefore, administrative convenience requires a more manageable test. Second, a manufacturer ought to have some protection against pertinacious rivals who might, by swiftly duplicating each new effort to distinguish his product by means of a trademark, prevent him from ever developing an easy means of commumicating with consumers. ${ }^{19}$

Thus under the M'Andrew rule, a tradesman could anticipate not only the protection of a well known mark, but also the exclusive right to use an incipient mark during the period necessary for it to become well known. Similar protection for a well known mark is logically compelled, and from this point onward a court could enjoin a second tradesman from using a first tradesman's mark regardless of the existence of passing off. The wrong thus becaine trademark infringement, not passing off, and an injunction against infringement could issue regardless of factors in defendant's marketing program indicating that defendant and not plaintiff supplied the product or service confronting the consumer.

American courts soon incorporated this English advance. The Seventh Circuit held in 1897 that trademark rights arise upon use of a mark affixed to a product rather than when the mark becomes as-

16. Id.

17. 32 L.J. 548 (Ch. 1863).

18. Id. at 551 .

19. Id. See Cope v. Evans, L.R. 18 Eq. 138 (1874). 
sociated in consumers' minds with a source. ${ }^{20}$ Otherwise, said the court, a tradesman could never establish a reputation except by the oversight of opportunitists who failed to strangle it at birth. In 1908, in a case where defendant adopted a mark similar to plaintiff's very soon after plaintiff's first use, a federal district court ruled that trademark rights accrue when a firm first uses the mark on a product. ${ }^{21}$ And in 1916 Judge Learned Hand reiterated the English rule and reasoning that since too much difficulty inheres in deciding when enough of the consuining public has associated a mark witl a source to justify protecting it only on that ground, "once ... [ [plaintiff's] use begins, the rest of the public must avoid his fanciful mark."22

Thus, from the clothier's case, where plaintiff recovered damages for passing off by simulating a inark, developed the omnibus case, where relief took the form of an injunction against further simulation by defendant of plaintiff's well known source symbols. From the omnibus case came the liquorice case, where relief took the form of an injunction against further use of plaintiff's little known source symbol. And from the liquorice case came the doctrine that a mark was protectable thougl only "technically" a trademark- "technically" because it was unknown by anyone, even defendant, at the time of defendant's use. ${ }^{23}$

\section{B. Marks of Service Firms and the Requirement of Affixation}

The protection of trademarks upon first use would logically be expected to give all tradesmen the opportunity, not adequately provided by the doctrine of passing off, to develop symbols pointing to their goods and services. Accordingly, a heating and cooling unit repair shop should be able to designate its building, "The House of Weather Magic" and feel confident of the availability of trade symbol protection. Other firms should, with similar confidence, be able to do business at locations displayimg terms such as "Ace Hardware," "State Farın Insurance Company," "Martinizing," "Chicago Title \& Trust," or "Arthur Murray's." Yet contrary to what Judge Hand's 1916 trademark pronouncement clearly suggested, ${ }^{24}$ many of these well known trade symbols became protectable only after long tenure in the market place, rather than upon first use.

20. Kathreiner's Malzkaffee Fabriken v. Pastor Kneipp Medicine Co., 82 F. 321 (7th Cir. 1897).

21. Walter Baker \& Co. v. Delapenha, 160 F. 746 (D.N.J. 1908).

22. Waldes v. International Mfgr's Agency, 237 F. 502, 505 (S.D.N.Y. 1916).

23. See Walter Baker \& Co. v. 'Delapenha, 160 F. 746 (D.N.J. 1908). On defendant's "innocence," see J.S. Tyree, Chemist, Inc. v. Thymo Borine Lab., 151 F.2d 621 (7th Cir. 1945).

24. Waldes v. International Mfgr's Agency, 237 F. 502 (S.D.N.Y. 1916). 
When judges developed the rule which protects a trademark upon first use, they apparently visualized a market featuring products but not services because when they designated the event which signals the acquisition of technical trade symbol rights, they chose the moment when a product bearing the symbol first confronted consumers in the market place-the time when the owner first "used" the symbol as a "trademark." The choice was not arbitrary. The courts sought an event other than achievement of notoriety, but they could not easily administer a test focusing upon such factors as a firm manager's conception of a symbol, his decision to use it, or his first steps to place it before consumers. Such tests, in addition to inviting perjured testimony, would hardly enable courts to resolve fairly and consistently all cases where rival firms claimed prior rights in similar marks. Instead, the courts, following the dictum in Hall v. Barrows ${ }^{25}$ and the holding in $M^{\prime}$ Andrew, ${ }^{26}$ chose affixation to a product and use in the market place, events easily proved, as the standard for determining when a firm acquired protectable trademark rights. ${ }^{27}$

Under the affixation test, or technical trademark standard, however, the "House of Weather Magic" cannot protect its trade syinbol in a suit against a rival who innocently appropriated a similar symbol shortly after its first appearance in the originator's sign, catalog or advertisement. ${ }^{28}$ Sign use, catalog use and advertising use do not qualify as trademark uses, because in such cases the symbol is not affixed to a product and does not, therefore, satisfy the affixation test. ${ }^{20}$ Consequently, firms that provide services receive protection for their trade symbols on a different, and more uncertain, basis than firms that affix their symbols to products. Unable to find affixation, the courts refuse to grant technical trademark protection, resorting instead to the traditional doctrine of passing off ${ }^{30}$ or to some variation thereof. They protect the unaffixed symbol when the second user adopts the symbol intending deception, ${ }^{31}$ or when the symbol has acquired, prior to the sec-

25. 32 L.J. 548 (Ch. 1863).

26. M'Andrew v. Bassett, 46 Eng. Rep. 965 (Ch. 1864). 1964).

27. Holsum Bakeries, Inc. v. General Baking Co., 228 F. Supp. 962 (E.D. La.

28. See Persha v. Armour \& Co., 239 F.2d 628 (5th Cir. 1957). Of course the "House of Weather Magic," in these circumstances cannot get protection under the passing off doctrine either because the symbol lacks sufficient notoriety.

29. American Components, Inc. v. Kent Corp., 160 U.S.P.Q. 335 (Tm. T. App. Bd. 1968) (sign on building); In re Marriott-Hot Shoppes, Inc., 156 U.S.P.Q. 257 (Tm. T. App. Bd. 1967) (symbol on place mat).

30. See, e.g., American Gold Star Mothers, Inc. v. National Gold Star Mothers, Inc., 191 F.2d 488 (D.C. Cir. 1951).

31. See Lincoln Restaurant Corp. v. Wolfies Restaurant, Inc., 291 F.2d 302 (2d Cir. 1961); LeFebure Corp. v. Lefebure, Inc., 284 F. Supp. 617 (E.D. La. 1968). See also Belle Harbor Catering Corp. v. Washington Hotel, Inc., 159 U.S.P.Q. 63 (N.Y. Sup. Ct. 1968). 
ond comer's use, a source significance among consumers indicating the first user. ${ }^{32}$ Under the latter principle a trade symbol receives full protection only upon proof that it had achieved notoriety-that significant numbers of consumers associated it with a source-at the time defendant simulated it. ${ }^{33}$ Thus, "distinctive" or well known symbols, ineligible for protection as technical trademarks because unaffixed or because otherwise inehibible, ${ }^{34}$ acquire protectable status as "non-technical" trademarks. Plaintiff, in a non-technical trade symbol suit, like his counterpart in a technical trademark case, can obtain an injunction against further trade symbol use by the defendant, regardless of the defendant's efforts to render his use non-confusing. ${ }^{35}$ "The House of Weather Magic," then, can receive trade symbol protection but only when consumers come to regard it as a source symbol for repair services.

32. See Safeway Stores, Inc. v. Chickasha Cotton Oil Co., 180 F. Supp. 534 (W.D. Okla. 1959); cf. Four Winds Travel, Inc. v. Jovien, 343 F.2d 653 (9th Cir. 1965).

33. As Prof. Derenberg pointed out long ago, English and American cases giving protection to such things as labels, packages, get-ups, names, marks and configurations, upon proof that consumers associated the item in question with a source, antedate the "technical" trademark cases. W. Derenberg, Trade-Mark Protection and UNfaIR TRADING \& 4 at 45-46 (1936). See generally id. \$\$ 4-7.

After the technical trademark evolved, that group of cases decided subsequent to the clothier's case and before the liquorice case retained full precedential value. Symbols not eligible as technical trademarks could still find shelter in cases like the omnibus case and Millington $v$. Fox, which, read together, teach that a court can give comprehensive protection to a well-known symbol even against an "innocent" defendant who intended no fraud. See W. DerenBerg, supra, $\$ 66$.

American judges and commientators became confused about the impact of the technical trademark doctrine on further developments under the passing off precedents. For a time some jurists thougit that the "old" precedents could control only cases of "intentional" dishonesty and could justify only limited imjunctive relief rather than an absolute restraint against any use by defendant of plaintiff's non-technical trade symbol. Handler \& Pickett, Trade-Marks and Trade Names-An Analysis and Synthesis, 30 CoLum. L. REv. 168, 759 (1930) (two parts) did much to lay that fallacy to rest although one commentator still expresses some doubt that American courts always protect fully both technical and non-technical trade symbols while recognizing still a third category for fraud or passing off that does not fit one of the two trademark categories. 3 R. Calimann, The Law of Unfair Competition, Trademarks and MONOPOLIES $\$ 86.1$ (a) (3d ed. 1970).

34. This Article does not treat all aspects of trademark law. One omitted aspect concerns the subject matter of trademarks. Some terms, generic terms and descriptive terms, for example, cannot become technical trademarks. In re W.A. Sheaffer Pen Co., 158 F.2d 390, 391 (C.C.P.A. 1946). Some potential source symbols, generic terms and functional features of products, for example, cannot become non-technical trademarks. Sears, Roebuck \& Co. v. Stiffel Co., 376 U.S. 225 (1964). Some potential source symbols, some unpatentable configurations of goods, for example, even if knowingly simulated by a defendant, cannot become the subject of a decree against passing off. Smith, Kline \& French Labs. v. Waldman, 69 F. Supp. 647 (E.D. Pa. 1946). Rather than treat those aspects of trade symbol law, this Article speaks of symbols "otherwise eligible" for protection as a technical trademark or "otherwise eligible" for protection as a non-technical source symbol. 
The courts' failure to protect arbitrary but unaffixed symbols upon first use in the market place makes lttle sense. The time of affixation does provide the most reasonable demarcation point when a firm ultimately affixes a symbol to a product, but the courts should extend protection to all arbitrary words and symbols on an equal basis-as of the time of first use to identify for consumers in any way a viable source of either products or services. A firm dealing only in services, which imtentionally uses a source symbol on a sign, in a catalog, or in an advertisement should receive protection on the same basis as the firm which affixes its symbol to a product. ${ }^{36}$ By failing to adopt this policy, the courts afford unfair deference to affixation. Yet, despite judicial, legislative and administrative efforts to bring legal protection to arbitrary but unaffixed symbols as of the time viable firms first use them to communicate information about source to the consuming pubhic, this logical, desirable and overdue advance remains unaccomplished. Part II of this Article will examine the impact of federal legislation on the service firm and part III will analyze the adequacy of the solution offered by the tentative draft of the Restatement (Second) of Torts.

\section{II}

\section{FEDERAL LEGISLATION AND TRADE SYMBOL PROTECTION}

The extension of legal protection for the unaffixed source symbols of service firms and firms dealing in products beyond the historical restraints of the affixation standard has depended primarily upon a complicated interaction of the provisions of the federal trademark statute $^{37}$ and the common law of the states. This part of the Article will examine the impact of federal legislation in providing the foundation for reform of the common law affixation requirement.

\section{A. The Service Mark Section of the Federal Trademark $A c t^{38}$}

Federal legislation on trademarks is by no means recent in origin. In 1879 in the Trade-Mark Cases $^{39}$ the Supreme Court invahidated the first federal act, the Trademark Act of $1870 .^{40}$ Congress next passed the Trademark Act of $1881^{41}$ which was superceded by the

35. Armstrong Paint \& Varnish Works v. Nu-Enamel Corp., 305 U.S. 315 (1938).

36. See text accompanying note 89 infra.

37. Trademark Act of 1946 \$ 1-45, 15 U.S.C. \$§ 1051-1127 (1964).

38. 15 U.S.C. $\$ 1053$ (1964).

39. 100 U.S. 82 (1879).

40. Act of July 8, 1870 , ch. 230,16 Stat. 198.

41. Act of Mar. 3, 1881, ch. 138, 21 Stat. 502. 
Trademark Act of $1905^{42}$ which, as amended in $1920,{ }^{43}$ was in turn superceded by the Trademark Act of $1946{ }^{44}$ amended in $1962 . .^{45}$

All of these federal acts have provided for registration and have shared the basic premise that registration does not generate trademark rights. ${ }^{46}$ An applicant for registration must first have a trademark, and whether he has one depends on a source of law other than the federal statute ${ }^{47}$ - usually state common law. ${ }^{48}$ Therefore, the federal legislation seems to imcorporate the affixation standard. The Trademark Act of 1946 does speak of more than technical trademarks however:

Subject to the provisions relating to the registration of trade-marks, so far as they are applicable, service marks used in commerce slaall be registrable, in the same manner and with the same effect as are trade-marks . . . .49

The Act defines a service mark as "a mark used in the sale or advertismg of services to identify the services of one person and distinguish them from the services of others." 50 One use of a mark in commerce occurs when the mark "is used or displayed in the sale or advertising of services and the services are rendered in commerce . . .."51 Prior to 1946 the term service mark had not appeared in common law decisions and prior trademark acts had not inentioned it.

A literal reading of the service mark provisions of the Act of 1946 suggests that Congress inay have invented the term to extend the benefits of registration to service marks which were ineligible for protection under state law because they were not affixed or because they had not acquired source significance. ${ }^{52}$ The language strongly suggests that a

42. Act of Feb. 20, 1905, ch. 592, 33 Stat. 724.

43. Act of Mar. 19, 1920, ch. 104, 41 Stat. 533.

44. Act of July 5,1946 , ch. 540,60 Stat. 427 (codified at 15 U.S.C. $\S \S 1051$ 1127 (1964)).

45. Act of Oct. 9, 1962, Pub. L. No. 87-772, 76 Stat. 769. For a history of trademark legislation, federal and other, see 4 R. CALLMANN, supra note 33, \& 97.1 (1970).

46. Campbell Soup Co. v. Armour \& Co., 175 F.2d 795 (3d Cir. 1949); 15 U.S.C. \$ 1051 (1964).

47. See note 46 supra.

48. Foreign law can also be a source of trademark rights. See 15 U.S.C. $\S 1126$ (1964).

49. Id. § 1053.

50. Id. § 1127 .

51. Id.

52. The Restatement (Second) of Torts says that a trademark "is affixed" to goods [Restatement (SECOND) of ToRTs $\$ 715(\mathrm{~b})$ (Tent. Draft No. 8, 1963)], and that "a designation becomes a trade-mark as soon as it is adopted and used as a trademark . . . but a designation is not a trade name until it has in fact become in the market the name for goods or services coming from or through a particular source or the name for a particular business." Id. \$ 716, comment (a). The Restatement 
service mark may be registered once it has been used in commerce, and that, once registered, it is ehigible for the same protection afforded registered trademarks. Such a reading, however, is inconsistent with the general prerequisite for registration under the Act of 1946: that the mark have protected status under a non-federal source of law.

A California federal district court faced this apparent imconsistency in 1953 and concluded that the Trademark Act of 1946 did not provide protection for service marks not in fact associated by consumers with a source of services. ${ }^{53}$ In that case, plaintiff insurance company had used an oxen-drawn covered wagon on its policies, its letterheads and in its newspaper and journal advertisements from 1926 to 1947, when it sought to register the symbol as a federal service mark. The registration issued in 1948 and thereafter, plaintiff brought an infringement action against a rival who used a similar symbol in its advertising and promotional efforts. The court ruled that plaintiff did not have a cause of action, because the Trademark Act of 1946 did not expressly extend service mark protection to every symbol used in advertising by a service organization..$^{54}$ Thus, the court implied that statutory protection extends only to service marks that have acquired an association with the services they represent. Nor can a court reasonably presume that such source associations arise merely because of long use of the symbol in advertising. ${ }^{55}$ For service mark rights to accrue to plaintiff, the evidence must establish that "those who deal with plaintiff, in fact, associate the covered-wagon mark with plaintiff's services in such a way that the mark perfornis a true service-mark function." ${ }^{56}$ The court concluded that plaintiff had not provided satisfactory evidence of secondary meaning and, as a result, did not have a valid service mark. ${ }^{57}$

further emphasizes that courts protect trade names only "if it is shown that persons are dealing with one business when they intended and thought they were doing business with another." Id. $\$ 716$, cominent (a). Protection is not afforded then, upon proof of simulation-as it would with a trademark-but only upon proof of confusion, which occurs only when the trade name has acquired a secondary meaning. That rule clearly applies even if the trade name is arbitrary. As the Restatement points out: "Tradenames which are dominated by a coined or made-up word may appear to receive wider protection than others, but this is because it is easier to make the showing of confusion in such cases." Id. The Restatement adds that "an advertising use of a designation for services may be sufficient to give it trade-mark status .... but the action is in the nature of one for unfair competition or false marketing rather than infringement of trade-mark." Id. $\$ 719$, comment (a).

53. Springfield Fire \& Marine Ins. Co. v. Founders' Fire \& Marine Ins. Co., 115 F. Supp. 787 (N.D. Cal. 1953).

54. Id. at 792-94.

55. See id. at 794-95.

56. Id. at 794.

57. Id. at 789-90. See Great American Ins. Co., 111 U.S.P.Q. -163 (Comm'n 1956) (allegation of secondary meaning). See also Younker v. Nationwide Mut. Ins. Co., 175 Ohio St. 1, 191 N.E.2d 145 (1963). 
Contrary to the California federal district court, most commentators assume or imply that any arbitrary service inark, as defined in the Trademark Act of 1946,58 becomes eligible for registration and acquires legally protected status the moment a use in commerce occurs. ${ }^{59}$

Unfortunately, the Patent Office, while approving many service mark registrations, has yet to speak clearly on whether it regards service marks as potentially protectable upon first use or whether it beheves some number of consumers somewhere must recognize the service mark as a source symbol before a valid registration can issue. Occasionally in a trademark proceeding before a Patent Office tribunal someone asserts that a particular service mark cannot qualify for registration because it falls into the descriptive term category, where all concede the need for secondary meaning. ${ }^{60}$ Sometimes in descriptive tern cases, lowever, the Patent Office tribunal labels the term in question not descriptive, thus reversing the contrary ruling of a lower tribunal and by so doing implying that a service mark applicant seeking to register a non-descriptive or arbitrary term need not offer proof of secondary meaning. ${ }^{61}$ At other times, the Patent Office seems to say that ouly marks associated by some with a source qualify for registration. ${ }^{62}$ Thus in The Little Studio, Inc. ${ }^{63}$ Assistant Commissioner Leeds wrote, somewhat ambiguously, "It may be that 'The Little Studio' has no significance to the public as a mark identifying applicant's services, but it is quite likely that it has such significance to artists and to the galleries . . . . Under such circumstances, it performs the function of a service mark." 64 Thus, although the service mark section of the Trademark Act of 1946 may be read to have introduced an unaffixed symbol pro-

58. 15 U.S.C. $\S 1054$ (1964).

59. E.g., D. Robert, The New Trade-Mark Manual 16 \& 40 (1947); E. VaNDenburgh, Trademark LaW aNd Procedure $\$ 1.30$ (2d ed. 1968). Under the Act, a use in commerce occurs when a mark "is used or displayed in the sale or advertising of service and the serviccs are rendered in commerce." 15 U.S.C. $\$ 1127$ (1964).

60. The Court of Customs and Patent Appeals has stated unequivocally that descriptive words sought to be registered as service marks must be known to consumers as source symbols. In re Standard Oil Co., 275 F.2d 945 (C.C.P.A. 1960); In re Standard Oil Co., 275 F.2d 735 (C.C.P.A. 1960); In re Campagnie Nationale Air France, 265 F.2d 938 (C.C.P.A. 1959). But these pronouncements help little in determining whether arbitrary service marks always qualify for protection and registration at the unoment of first use. Even an affixed designation consisting of matter merely deseriptive of the apphicant's goods cannot be registered under the federal act absent proof that the trademark has become distinctive of the applicant's goods in commerce. Since section three of the Act makes service marks subject to the provisions of the Act relating to the registration of trademarks, a construction of the Act putting descriptive service marks on an equal footing with descriptive trade-marks seems sound.

61. E.g., Colvin, Mendelhall \& Co., 98 U.S.P.Q. 415 (Comm'n 1953).

62. Cf. Carter Publishing, Inc., 92 U.S.P.Q. 251 (Comm'n 1952).

63. 111 U.S.P.Q. 224 (Comm'n 1956).

64. Id. at 225 . 
tectable upon first use-a "technical service mark"-if it did so, the advance has gone relatively unheralded. ${ }^{65}$

\section{B. Patent Office Prerequisites for Federal - Trademark Registration}

Despite the ambiguities and consequent dormancy of its service mark sections, another section of the Trademark Act of 1946 has shown potential for fostering first use protection for service marks or unaffixed trademarks which eventually could abrogate the affixation requirement. Section 2(d) of the Act authorizes the Patent Office to refuse to register a trademark which so resembles a non-abandoned trade name previously used in the United States by another as to be likely to cause confusion among consumers if affixed to the goods of the apphicant. The term "trade name" obviously means unaffixed symbol. ${ }^{66}$

One might expect that a trade name having a sufficient reputation, within the meaning of section 2(d), to prevent registration of a trademark would, of necessity, have significance in some market as a symbol of source. But section 2(d) has not been given that construction, for the Patent Office tribunals have focused on the question of whether

65. Admittedly, a construction of the Trademark Act of 1946 which eliminates the requirement of a source association for service marks would not be easily accomplished. Service marks, hike trademarks, might be subject to the section one requirement that marks be "owned" prior to application for federal registration. 15 U.S.C. $\S 1051$ (1964). Moreover, the definitions of service marks and service mark uses in commerce might very well constitute inerely federal criteria for registration of staterecognized symbols and thus, may not be relevant to the basic question of when service mark rights accrue. Compare E. VANDENBURGH, supra note 55, at 24 n.18, where the author states that a party who "affixed" his trademark according to the standards of the Trademark Act of 1946, but whose use did not qualify as "affixed" under the common law, could lose priority to a second comer who first unade a valid common law affixation.

Federal courts and agencies have thus far refused to recognize as "services" or as service mark "uses" everything that applicants for service mark registrations have tendered as appropriately used service marks. See, e.g., In re Radio Corp. of America, 205 F.2d 180 (C.C.P.A. 1953); Tampax, Inc., 91 U.S.P.Q. 215 (Comm'n 1951); Pacific Coast Aggregates, Inc., 91 U.S.P.Q. 210 (Comin'n 1951).

66. At one time, at common law, insofar as agreement among judges and jurists existed, "trade name" meant any protectable affixed or unaffixed trade symbol except a "technical" trademark. Later, again, insofar as agreement existed, trade name meant any protectable unaffixed syinbol. In both instances trade names achieved status only by reason of their source significance to consumers. Symbols currently defined as service marks under the Trademark Act of 1946 fall, because unaffixed, into the old common law trade name category. In addition, the Act defimes trade names as including "individual names and surnames, firm names and trade names used by manufacturers . . . and others to identify their businesses, vocations or occupations [and] the names or titles lawfully adopted and used by firms . . ." 15 U.S.C. \& 1127 (1964). Owners of trade names cannot register them under the Act unless they qualify as trademarks, service marks, collective marks or certification marks. 
a registration will prejudice consumers who are likely to become confused because of the existence of a similar competing symbol and have not required that the competing symbol have source significance.

In Alfred Electronics v. Alford Manufacturing Co. ${ }^{67}$ the Court of Customs and Patent Appeals affirmed the cancellation of a registration of "Alfred" on the ground that it so resembled "Alford," a trade name previously used in the United States by another, as to be likely, when affixed to registrant's goods, to cause confusion. The successful party had used "Alford" as a trade name roughly eleven months before the other party had so used "Alfred." Each subsequently affixed his symbol to a product, first Alford, then Alfred. The court, however, affirmed cancellation of Alfred's registration because of Alford's prior trade name use, irrespective of the affixation dates. ${ }^{68}$ In so affirming the cancellation of Alfred's registration, the court significantly departed from the traditional common law requirements by holding that section 2(d) does not require either that a trade name be arbitrary or that it have source significance. Thus, one who has used an unaffixed symbol, either arbitrary or descriptive, has standing to oppose and attempt to cancel a subsequent user's federal trademark registration.

While this negative power to thwart attempts by others to register trademarks does not confer a right of registration, or an exclusive right in the symbol, it is nevertheless very significant in that it has led to the erosion of the affixation requirement. In John Wood Manufacturing Co. v. Servel, Inc., ${ }^{69}$ a party who sold Electrolux refrigerators, designating one of its models as "Hostess," successfully opposed a rival's application for registration of "Hostess" for refrigerators, asserting that the opposing party had been using "Hostess" as a refrigerator grade mark - a quahty indicator with no source significance ${ }^{70}$ - continuously for four years prior to the apphicant's first use of "Hostess" as a trademark. The court held in favor of the intervenor, saying that he need not establish a trademark use of "Hostess"-use as a source symbolto defeat the application. Otherwise, said the court, opportunists could appropriate non-technical or unregistered symbols made strong by others merely by affixing the symbols to a product and using them as technical trademarks. ${ }^{71}$

67. 333 F.2d 912 (C.C.P.A. 1964). See also California Piece Dye Works v. California Hand Prints, Inc., 159 F.2d 871 (C.C.P.A. 1947).

68. The Patent Office's willingness to look at pre-affixation use, which both parties could show, to determine priority made it difficult for the court to state a simple preference for the first to affix. 333 F.2d at 917.

69. 77 F.2d 946 (C.C.P.A. 1935).

70. At common law, the use of a symbol as a grade mark gives no rights against one who subsequently uses the symbol as a trademark. Reid, Murdock \& Co. v. H.P. Coffee Co., 48 F.2d 817 (8th Cir. 1931).

71. 77 F.2d at 949. Accord, Lever Bros. Co. v. Nobio Prods. Co., 103 F.2d 917 (C.C.P.A. 1939). 
The Trademark Trial and Appeal Board recently extended this principle. ${ }^{72}$ An applicant sought a registration for "Daltronix" for sound system components. Daltronics Incorporated opposed the apphication, asserting that it had used "Daltronics" in marketing sound system components before apphicant used "Daltronix." The opposer had imcorporated in February 1961, using "Daltronics" in its corporate name. In Septeniber 1961, it used "Daltronics" in advertismg material calculated to extoll the firm's wares and capture consumer interest, and in 1961-62 it featured the word in prominent script on packages containing equipment sold in small quantities. Although the apphicant for registration alleged a trademark use of "Daltronix" im August 1963, and continuously thereafter, the Board sustained the opposition and denied the application for registration saying that the opposer's prior use of "Daltronics" as either a trademark or a trade name would defeat the application for registration. More specifically, the Board held that use of a designation as a dominant or significant feature of a trade name creates rights in the user sufficient to preclude registration by a subsequent user of a similar designation, even though the subsequent use satisfies trademark affixation requirements. ${ }^{73}$ The Board indicated that opposer's use of "Daltronics" in advertisements created an impression among consumers that "Daltronics" indicated a source, and that section 2(d) precludes the registration of a mark which so resembles a trade name previously used by another as to be likely to cause confusion. ${ }^{74}$ But, continued the Board, that section does not require that the trade name be inherently distinctive, that it have significance in consumers' minds as a source synubol, or that it have been widely used. "It is sufficient," said the Board, "that such use as a trade name be prior and continuous."75 The Board concluded by permitting the opposer to rely

72. Daltronics, Inc. v. H.L. Dalis, Inc., 158 U.S.P.Q. 475 (Tm. T. App. Bd. 1968).

73. Id. at 479 .

74. Id. at $479-80$.

75. Id. at 480. In many cases, the Patent Office has sustained an opposition to an application for registration upon the opposer's showing a prior advertising use of a similar symbol in connection with the marketing of related products, and the Patent Office has done so without commenting directly on the impact on consumers' minds of the opposer's advertising use or trade name use of the symbol. E.g., Brooklyn Folding Box Co. v. Poland Bros., Inc., 131 U.S.P.Q. 43 (Tm. T. App. Bd. 1961); Midwest Homes, Inc. v. Midwest Houses, Inc., 120 U.S.P.Q. 406 (Comm'n 1959) (name use); Botany Mills, Inc. v. Atlantic Knitting Mills, Inc., 104 U.S.P.Q. 354 (Comm'n 1955); E.P. Lynch, Inc. v. W.J. Lynch Paint \& Varnish Co., 93 U.S.P.Q. 181 (Comm'n 1952); Fourco Glass Co. v. Libbey-Owens-Ford Glass Co., 97 U.S.P.Q. 181 (Examiner 1953). Prior to the Daltronics decision, the Patent Office tribunals, in general, required an applicant relying on prior advertising use or trade name use to show that his designation has become "popularized and identified im the publio mind with opposer's product." Woodmark Originals, Inc. v. Purofied Down Prods. Corp., 157 U.S.P.Q. 543 (Tm. T. App. Bd. 1968). Jacobsen Mfg. Co. v. Automatic Associates, 
on February 1961 as its date of first use for purposes of opposing its rival's application. Since that date was the date of the opposer's incorporation, public use of "Daltronics" in advertising or on signs on buildings probably did not occur until much later. In permitting the opposer to rely on its date of incorporation to show prior use of "Daltronics," the Trademark Trial and Appeal Board completely abrogated the affixation requirement. Indeed the Board appeared to go behind even the date of first public use to determine the accrual of rights to unaffixed, arbitrary symbols. ${ }^{76}$

In another series of cases, unrelated to section 2(d), the Patent Office has also undermined the significance of affixation for trademark registration. The Patent Office has held that use of a symbol in advertising or on signs, truck panels, or buildings, though not in itself sufficient to support an application for registration, ${ }^{77}$ may help an applicant succeed in obtaining a federal trademark registration for a symbol that the applicant subsequently affixes to a product, even though another party affixes first. For exainple, in International Telephone \& Telegraph v. General Instrument ${ }^{78}$ both parties souglit to register similar inarks for similar products, International showing affixation as of May 21, 1962, and General Instrument showing affixation as of May

Inc., 149 U.S.P.Q. 651 (Tm. T. App. Bd. 1966).

But Daltronics greatly weakens the "popularization" requirement of cases like Woodmark and Jacobsen. In fact the Daltronics opinion cites Jacobsen to show that the applicant in Daltronics could not itself rely on a use of "Daltronix" in the body of a statement prepared by applicant's printer but never shown to have come to the attention of the public. Thus an opposer relying on prior advertising or similar use need not show secondary meaning or anything like it but must show that the user intended the use to make an impression as a source symbol upon the public; the user need not show that he succeeded. Cases where the record shows that opposer carried the pre-Daltronics burden of proof on "impressing the public" include: Cities Serv. Oil Co. v. Perfection American, Inc., 157 U.S.P.Q. 209 (Tm. T. App. Bd. 1968); Trane Co. v. W-M Mfg. Co., 138 U.S.P.Q. 163 (Tm. T. App. Bd. 1963) (Board emphasized that opposer made a public use analogous to a trademark use); Farrington Mfg. Co. v. Le Febure Corp., 120 U.S.P.Q. 93 (Comm'n 1959); Creamette Co. v. Dispensers, Inc., 102 U.S.P.Q. 423 (Comm'n 1954); and Motorola, Inc. v. Seigel, 88 U.S.P.Q. 436 (Examiner 1951).

76. Most states by statute prohibit a new corporation from adopting a name identical to or similar to a corporate name already in use. But these statutes do not, in the usual case, confer exclusive rights in the corporate name or in any way impinge upon trade symbol doctrine. $6 \mathrm{~W}$. Fletcher, Cyclopedia of the LaW of Private CoRporations $\S 2415$ (perm. ed. rev. 1968). The corporate name statutes for the 50 states, the District of Columbia and Puerto Rico are summarizcd in 1. H. OlECR, Modern Corporation LAW $\$ 402 f f$ (1958). See Worthey, Corporate Names: Their Selection and Use, 52 Trademarar Rep. 91 (1962). Compare Ezrin, Protection of Corporate Names Under the Lanham Trademark Act-Corporations Are "Persons" Under Section 2(a) Via the "21" Club Case, 56 TRADEMARK REP. 391, 393-94 (1966).

77. Boss Co. v. Homemaker Rugs, Inc., 117 U.S.P.Q. 255 (N.D. Ill. 1958); In re Webcor, Inc., 122 U.S.P.Q. 97 (Tm. T. App. Bd. 1959).

78. 152 U.S.P.Q. 821 (Tm. T. App. Bd. 1967). 
29, $1962 .{ }^{79}$ The Patent Office denied the former's application and granted that of the latter because General Instrument showed advertising and packing slip use froin July, 1961. The Board stated that priority does not turn only on affixation. Prior use in a manner "analogous to tradeinark uses," such as use of the symbol in the sale, advertising, or promotion of goods, can vest trademark rights in one who thus uses a symbol even as against a rival who first makes a trademark use of the symbol by affixing it to a product. ${ }^{80}$ According to the Board, the "analogous" use which will vest trademark rights in a syınbol must be sufficiently extensive to create an association of the goods with the user in the mind of the purchasing pubhic. ${ }^{81}$

Since International apparently had secondary meaning rights in the symbol prior to General Instrument's attempt to acquire technical trademark rights by affixation, the result in the International Telephone \& Telegraph case appears conventional. However, the general willingness of the Patent Office and the Court of Customs and Patent Appeals to weigh advertising and promotional use in determining priority both in opposition proceedings and in registration proceedings, and the ease with which opposers and applicants can satisfy the requirement that uses "analogous to trademark uses" be open, public and calculated to create source significance in consumers' minds, suggest that affixation will have considerably less importance in the law of trademarks and service marks in the future. The Board's willingness to assign significance to the date a party includes a symbol in a corporate name, in the Daltronics ${ }^{82}$ case, and the willingness of the Court in Alfred Electronics ${ }^{83}$ to prefer the first user, in a context where the symbol probably had not acquired an extensive repute in the market place at the time the second user appropriated it, suggests that henceforth a public use by a going concern of an arbitrary symbol calculated to attract the attention of consuiners as a source syinbol will vest exclusive rights in the user as of the date of first public use, regardless of affixation and regardless of the likely absence, on that date, of widespread understanding among consumers that the symbol indicates source.

\section{Federal Law and State Developments}

Some of the conceptual difficulties associated with federally registered service marks would be resolved if the states would accord first use

79. Id. at 823 .

80. Id. at 824 .

81. Id. Accord, Sears, Roebuck \& Co. v. Mannington Mills, Inc., 138 U.S.P.Q.

261 (Tm. T. App. Bd. 1963).

82. See text accoinpanying notes 72-76 supra.

83. See text accompanying note 76 supra. 
protection to service marks. Moreover, federal tribunals could, more justifiably, attach significance to pre-affixation advertising uses of trademarks if the states would accord first use protection to unaffixed trademarks. Conceivably, the federal service mark provisions and the importance attached by the Patent Office and the federal courts to advertising and promotional uses of symbols in deciding questions under the federal act will influence state tribunals to modify state trade symbol doctrines, at least to grant protection as of the time of first use to arbitrary symbols used in a way likely to create source significance. The state courts could find in federal statutes and court decisions an expression of policy which will support efforts to adapt and change trade symboll law.

Indeed, there is authority which indicates that further developments in state trade symbol law liave already begun in the federal courts. In American Plan Corp. v. State Loan \& Finance Corp.,${ }^{84}$ plaintiff, who did a national business arranging insurance contracts under its corporate name, The American Plan Corporation, souglit to enjoin defendant from adopting and using the same name to identify its small loan subsidiaries. After plaintiff presented its case, the United States district court dismissed the complaint on the ground that plamtiff failed to show that American Plan Corporation signified a commercial source to consumers. ${ }^{85}$ The Third Circuit reversed, saying that under Delaware law a court can protect a trade name without proof of secondary ineaning-source significance among consumers-if the term is "capable of exclusive appropriation." arbitrary and fanciful words, as opposed to descriptive and generic terms, as "capable of exclusive appropriation" and labeled "American" arbitrary. ${ }^{87}$ Since defendant's busmess name did not differ from plaimtiff's, the court held that the names themselves demonstrated future, if not present, likelihood of confusion. ${ }^{88}$

Since the Delaware state court precedents cited by the Third Circuit do not appear to offer strong support for the federal court's conclusion, ${ }^{89}$ the American Plan case illustrates one manner in which federal policy might influence the development of state law.

84. 365 F.2d 635 (3d Cir. 1966).

85. Id. at 637 .

86. Id.

87. Id. at 638 .

88. Id. at 639 .

89. The Third Circuit cited five cases. Three, United States Plywood Co. v. United Plywood Corp., 19 Del. Ch. 27, 161 A. 913 (1932), Standard Oilshares Inc. v. Standard Oil Group, 17 Del. Ch. 113, 150 A. 174 (1930), and Drugs Consol. Inc. v. Drug Inc., 16 Del. Ch. 240, 144 A. 656 (1929), involved decisions for defendant in which the court found no basis for protecting plaintiff. The fourth, Delaware Charter Co. v. Delaware Charter Serv. Co., 16 Del. Ch. 246, 144 A. 659 (1929), like the 
There are signals which indicate that such holdings by other federal courts and by state courts may be impending. For example, a California federal district court has recently stated that a court can protect a non-descriptive syinbol-in this case "7-Eleven"-as a "technical trade name" as of the time the owner originally adopted and used it. ${ }^{90}$ A similar, though broader dictuin issued from a New York state court 15 years earlier: "the law of unfair competition no longer requires that plaintiff's business and advertising shall have acquired a 'secondary ineaning." ",91

State legislatures also concern themselves occasionally with trade symbols and could pass comprehensive trade symbol codes embracing those facets of the common law which are acceptable and reshaping the law in areas where coinmon law developinents have been arrested. By 1967, all 50 states had soine kind of a state trademark registration scheme $^{92}$ and 36 states liad adopted, often with changes, the Model State Trademark Bill, ${ }^{93}$ drafted prior to 1950 with the assistance of the United States Trademark Association. By 1967, 30 states provided for the registration of service inarks. ${ }^{94}$

In the past, courts have apparently unifornily construed state trademark statutes as supplementing the common law without significantly altering it. ${ }^{95}$ Under nost state statutes, to qualify for a state trademark registration, an applicant must first acquire a common law mark. $^{96}$ The Model State Trademark Bill ${ }^{97}$ also fails to abridge sig-

Drugs Consolidated case, supra, involved application of a subsequently amended section of the Delaware General Corporation Law which required corporations to choose a name that "shall be such as to distinguish it from any other corporation engaged in the same business . . . ." Id. at 246, 144 A. at 659 .

The fifth case, American Radio Stores, Inc. v. American Radio \& Television Stores Corp., 17 Del. Ch. 127, 150 A. 180 (1930) - the case most nearly in pointhas a confusing opinion. The court protected plaintiff's name from defendant's use of it upon finding actual confusion, which suggests a test of secondary meaning. The opinion also has passing off overtones and the case cited by the American Radio court, Shaver v. Heller \& Merz Co., 108 F. 821 (8th Cir. 1901), protected "American," after labeling it descriptive, on the ground that it had a secondary meaning which defendant attempted intentionally to exploit by passing off. (dictum).

90. Southland Corp. v. Schubert, 160 U.S.P.Q. 375, 388 (C.D. Cal. 1968)

91. Santa's Workshop, Inc. v. Sterling, 282 App. Div. 328, 122 N.Y.S.2d 488 (1953). And see Avon Periodicals, Inc. v. Ziff-Davis Pub. Co., 282 App. Div. 200, 122 N.Y.S.2d 92 (1953).

92. State Trademark Registration, 57 TRADEMARK REP. 886 (1967).

93. Id.

94. Id.

95. E.g., Coca-Cola Co. v. Stevenson, 276 F. 1010 (S.D. Ill. 1920) (Illinois statute).

96. Bayuk Cigars, Inc. v. Schwartz, 1 F. Supp. 283 (D.N.J. 1932) (New Jersey statute).

97. Reproduced in E. VANDERBURGH, supra note 59, at 571. 
nificantly common law concepts by permitting registration only to a person who first "adopts and uses a trademark," tioning service marks, and by stating that nothing in the Bill "shall adversely affect the rights or the enforcement of rights in trademarks acquired in good faith at any time at common law." Us Usually, those states with trademark statutes not based on the Model State Trademark Bill also follow the general practice of not tampering significantly with common law doctrine, at least with regard to trademarks for product firms. ${ }^{100}$

Notwithstanding this typical adherence to traditional common law doctrine, there are indications of legislative reform. Approximately 30 state legislatures have already accomphished significant reform in the area of first use mark rights for service firms by enacting statutory provisions recognizing service marks. ${ }^{101}$ In 1967, California, for example, passed a new chapter ${ }^{102}$ regulating the registration and protection of trademarks which extended statutory protection to service marks ${ }^{103}$ -marks "used in the sale or advertising of services to identify the services of one person and distimguish thein froin the services of others."104 California extends the privilege of registration to any service mark by which the services of any applicant "may be distinguished" from the services of others, ${ }^{105}$ thus suggesting first use protection rather than long use protection, and makes the certificate of registration prima facie evidence of ownership. ${ }^{106}$

The California Legislature has thus provided for a first use service mark unless this concept is eroded by strict judicial interpretation of the statement that "nothing in this chapter shall adversely affect the rights or the enforcement of rights in marks acquired in good faith at any time at common law."107 New York similarly provides for a first use serv-

98. Section 3, id. at 572.

99. Section 13, id. at 577 (emphasis added).

100. See State Trademark Registration, supra note 92. However, Tennessee appears to have an exceptional section in its act, giving the right to a certificate of record constituting prima facie evidence of adoption of a trademark to any applicant who files a sworn application specifying, among other things, the firm on whose behalf the application is filed and "a description of the goods to which it has been, or is intended to be appropriated"” 12 TENN. CODE ANN. $\$ 69-502$ (1955). See also the West Virginia statute, W. VA. CODE ANN. \$ 47-2-2 (1966).

101. State Trademark Registration, supra note 92.

102. Cal. Bus. \& Prof. CODE $\S \S 14000-292$ (West Supp. 1970).

103. See generally Sutton, California "Model" Trademark Act: A Comparison With Federal Law, 2 U.S.F.L. REv. 198 (1968).

104. Cal. Bus. \& Prof. Code $\$ 14206$ (West Supp. 1970).

105. Id. § 14220 .

106. Id. \& 14241 .

107. Id. $\$ 14210$ (emphasis added). Suppose $A$ uses "The Shanty" for a steak house in San Francisco and immediately obtains a registration. Suppose $B$ shortly thereafter uses "The Shanty" for a steak house in another part of San Francisco. $A$ 
ice mark, although a New York certificate is prima facie proof only of registration, not ownership. ${ }^{108}$ New York likewise states that nothing in its trademark act shall "adversely affect the rights or the enforcement of rights in marks acquired in good faith at any time at common law."109 Texas appears likewise to provide by statute for a first use service mark $^{110}$ but defines a registrable mark as one in actual use "which distinguishes" apphicants' services from those of others ${ }^{111}$-as opposed to California's "mark by which the goods or services . . . may be distinguished."112 Texas also disables a registration from adversely affecting common law rights acquired prior to registration but at the same time disables nonregistrants from acquiring common law rights in any registered symbol during the period when a registration is in force. ${ }^{113}$

As the references to the California, New York and Texas statutes suggest, while state legislative refornıs in the area of first use service marks have occurred, state legislatures' penchant for expressing directly and indirectly a legislative purpose not to derogate the common law of trade symbols poses some severe construction problems for the courts.

\section{III}

\section{THE RESTATEMENT OF TORTS}

The Restatement (Second) of Torts has become a focal point for further change in the common law of trademarks and service marks. The present tentative draft, perhaps recognizing that affixation may become obsolete in the law of trade symbols, redefines a trademark as a symbol used on or in connection with goods or services in a manner which both identifies them as those of a particular firm and also distinguishes them from those of other firms. ${ }^{114}$ The Restatement draft states further that a designation adopted for the purpose of identifying one's goods or services and distinguishing them from those of others becomes a trademark: For goods when it is displayed on the goods

sues $B$ for infringement of a registered service mark. $B$ proves that "The Shanty" has a secondary meaning pointing to $B$, and that it has no secondary meaning pointing to $A$ and asks that his common law secondary meaning mark take precedence over $A$ 's registered mark. What result? See id. $\S 14342$, which suggests that a registered service mark owner must defer to a prior user's similar mark even if the prior user had no secondary meaning at the time of registration or the time of suit.

108. N.Y. GeN. Bus. LaW \$ 363 (McKinney 1968).

109. Id. § 368-e.

110. Tex. Code Bus. \& Com. ANN. $\S 16.02$ (1968).

111. Id. $\$ 16.08$.

112. Cal. Bus. \& Prof. Code \& 14220 (West Supp. 1970).

113. Tex. Code Bus. \& CoM. ANN. $\$ 16.27$ (1968).

114. Restatement (SeCond) of Torts $\$ 715$ (Tent. Draft No. 8, 1963). 
or their labels or containers, or is otherwise directly associated with the goods in the marketing process near the point of purchase by consumers; and, for services, when it is displayed in the advertising, sale or performance of services. ${ }^{115}$

Thus, the Restatement scheme solves the problem of affixation for service firms, but it partially retams the traditional requirement of affixation for firms dealing in products. Restatement commentary does not explain why firms dealing in products should not, with service firms, obtain rights in arbitrary trade symbols upon first public use of the symbol in advertising. One possible explanation might be a fear that opportunists, by periodic advertising efforts not in any way connected with a serious business enterprise, could preempt symbols solely for the purpose of selling their colorable trade symbol claims. However, the Restatement risks this possibility when service firms are imvolved. Moreover, in both service imdustry and product industry cases, courts can refuse to recognize trade symbol rights for firms not using trade symbols to communicate with consumers in connection with a marketing effort reasonably calculated to bring products or services to the market expeditiously. ${ }^{116}$

A second possible explanation for the Restatement position lies in the potential for consumer deception inherent im the practice of advertising a product which cannot be identified as the subject of the advertisement by consumers at the point of purchase. Indeed, in Western Stove Co. v. Geo. D. Roper Corp. ${ }^{117}$ the court held that advertising a product in connection with a trade symbol which the advertiser has not affixed to the product does not secure mark rights. The court posed the hypothetical case in which an advertiser who retailed stoves advertised his best stoves as "Town \& Country" but did not affix "Town \& Country" to any stove of any grade in his inventory. The court apparently was concerned that consumers responding to such an advertiseinent would prove easy prey for a salesman who could designate any stove in stock as "Town \& Country" without fear that a mark or label on another appliance would contradict him. ${ }^{118}$

115. Id. § 719.

116. 3 R. CallmanN, supra note 33 , at $\$ 76.2$ (d). Professor Callmann marshalls authorities for the proposition that, to acquire trade symbol rights, a firm at present must actually be in operation before the public. Id. The draftsmen of the Restatement section on service marks could have expressed a similar condition for acquiring service mark rights. Such a requirement doubtless would commend itself to courts and agencies faced with claims of rights in unaffixed trademarks, and would serve to screen from consideration many instances of sham uses that might otherwise appear troublesome.

117. 82 F. Supp. 206 (S.D. Cal. 1949).

118. Id. at 214. 
This fear seems justified, but a court can minimize the risk in better ways than by denying protection to producer's unaffixed marks. Perhaps putative inark owners should put their symbols upon products that they have available for purchase at retail outlets as well as upon their advertisements. Yet the stove retailer who worried the court in Western Stove could bilk consumers as easily, and with equal prospects for profit, by affixing "Town \& Country" to stoves of varying quality as by leaving stoves of varying quality unmarked. Although deception of the latter variety inay be somewhat more difficult to detect, it seems that the opportunity for consumer deception does not depend entirely upon whether trade syinbols used in advertising are also attached to products in retail inventories. Thus, it would appear that the question of a sanction for a producer's failure to mark goods held in inventory bears scant relation to the question of whether producing firms can acquire trademark rights witlout complying with an affixation rule. Moreover, courts or legislatures can both recognize that trademark rights accrue on first use, in advertising or on products, and require firms owning marks to affix thein to products.

The Restatement draft, in addition to discussing trademarks also recognizes trade names and distinguishes them froun trademarks for goods or services by saying that trade naunes symbolize business good will, while tradeinarks symbolize product or service good will. ${ }^{110}$ The Restatement excludes symbols classified by it as trade names-symbols used to identify a business, as opposed to a product or servicefrom protection upon first use whether used by dealers in products or dealers in services. ${ }^{120}$

The exclusion of trade names from the category of symbols protectable upon first use seems unreahistic because of the attempted distimction between product good will and firm good will. Firms turn out products and services by constantly using up units of labor and quantities of raw materials and machines. Machines wear out, managenent turns over, workers come and go and the sources and quality of raw materials and component parts change. ${ }^{121}$ Such a process in effect turns out products and services in "batches," with a batch defined as a quantity of output from a production process which utilizes nearly identical units of labor, capital, and raw materials. Consumers can purchase products from the same "batch" with assurance that the quality of a recently purchased product will match the quality of a formerly purchased product from the same batch. In that sense, the

119. Restatement (Second) of ToRTs $\$ 716$ (Tent. Draft No. 8, 1963).

120. Id.

121. See Treece, Trademark Licensing and Vertical Restraints In Franchising Arrangements, 116 U. PA. L. REV. 435, 439-45 (1968), and sources cited therein. 
product has good will, and if its trademark serves as a batch number, its trademark mdicates product good will. Where consumers can identify batches, they can seek products from the batch that served them or their acquaintances well before. But most purchases of trademarked products-vegetables, automobiles, perfume, soft drinks, clothing, pizzado not involve consumers using trademarks to guide them to a desired batch. Most purchases of trademarked products involve consumers using trademarks to guide them to a firm that made a product that served someone well before. Such consumers, in effect, bet that the firm owning the mark serving as their guide controls the quality of constantly changing factors of production in such a way that batches of products produced at different times will not vary substantially in quality. Such consuiners pursue business goodwill, not product or service good will, for they depend upon the integrity of the firm, not the integrity of the batch. Consequently, it seems fair to state that most trade names and most trademarks symbolize business goodwill, not product or service good will. Therefore, the Restatement's attempt to relate trademark protection exclusively to product good will and trade name protection exclusively to busmess goodwill appears to ignore the conduct of producers and the conduct of consumers. The Restatement's trade name serves the same function as a trademark or service mark. It provides the consumer with a shorthand means of connecting a product or service with a source and of recalling for utilization information previously acquired about the source. It sliould, therefore, qualify for legal protection on the saine basis as a service mark-if an arbitrary term or designation-at the moment of first use as a source symbol.

\section{CONCLUSION}

A history of trade symbol protection shows that the law has given protection to symbols at progressively earlier stages of their marketing "hives." The common law began this trend and, in the United States, state and federal legislation has furthered it. Presently, in the Umited States, the common law, state statutes and federal legislation co-exist as sources of trade symbol law. The federal statute builds upon state law and, usually, state trademark legislation builds upon state common law. Congress' unnecessary deference to state law as a source of substantive rights in trade symbols and state legislatures' unnecessary deference to the common law of trade symbols, however, have slowed the pace of developments in trade symbol law in the United States in the twentieth century.

Product firms and service firms feel the need for security in their 
choices of source symbols at the time of the choice. ${ }^{122}$ Service firms do not have such security if the law protects only well-known source symbols and time must pass before a selected mark can become wellknown. Product firms do not have such security if the law protects only affixed source symbols and time must pass before a product can be produced and a selected mark affixed.

Simce sound trademark policy favors giving the maximum security at an early date to firms choosing source symbols, the common law should develop criteria for accomplishing the desired result. The common law should select an event or events $\mathrm{m}$ addition to affixation of a symbol-any first use of the symbol to communicate with consumersto signal the acquisition of trade symbol rights. The Third Circuit has demonstrated how easily and appropriately a common law court can secure first use trade symbol rights for a service firm. ${ }^{123}$ Other courts have extended protection for product firms by broadening the concept of affixation to include uses of the symbol in displaying the product which would not have constituted "affixation" as traditionally defined.

The Restatement, however, with its imsistence upon affixation for product marks and notoriety for trade names may halt or inhibit the discernible common law developments toward first use protection. But perhaps the Restatement will be redrafted, for it is untikely that the draftsmen will long hold the view that consumers' mental processes will conforni to the Restatement's artificial categories. Meanwhile, courts and agencies should ignore the Restatement's tenuous distinctions between symbols pointing to products and symbols pointing to firms, and distinctions between firms dealing in products and firms dealing in services. Designations used as source symbols have the same impact on consumers' minds whether appearing on a label affixed to a product, in advertisements in tangible media, or in messages communicated by radio or television transinissions. ${ }^{124}$ If the source represents itself as a going concern and communicates its symbol to consumers in a manner such that consumers can comprehend the symbol, remember it, and use it im future purchasing decisions, then courts should protect the symbol as of this date of first public use to establisli source significance. Clearly, not all uses of a symbol in the print or broadcast media

122. See, e.g., the dialogue between lawyer and corporation president in Dalsimer, Intention to Use-A Proposal (Pro), 53 TRADEMARK REP. 975, 975-78 (1963).

123. American Plan Corp. v. State Loan \& Fin. Corp., 365 F.2d 635 (3d Cir. 1966).

124. See, e.g., Motivation AND MaRKet Behavion (Ferber \& Wales eds. 1959); T. Levitt, Industrial Purchasing Behavior: A Study of Communications Effects (1965); Burdick, Green \& Lovelace, Predicting Trademark Effectiveness, 43 J. APPLIED PSYCH. 285 (1959). 
should confer trade symbol rights. However, precedents interpreting the concept of affixation have distinguished intended uses from casual uses, grademark uses froin trademark uses, sporadic uses from continuous uses and bona fide uses from devious uses. ${ }^{125}$ These decisions should aid courts and agencies in distinguishing uses effective to confer mark rights from uses ineffective to confer mark rights when affixation is not present.

The developinent of a doctrine of first use protection will, however, require judicial and administrative creativity since the ambiguity in many state trademark statutes precludes coinfortable guidance. Most of these statutes that mention service marks appear to alter the common law of trade symbols by giving first use rights in unaffixed, arbitrary marks to service firns. ${ }^{126}$ However, the great majority of state trademark statutes are based on the Model State Tradeinark Bill and contain a provision disclaiming any intention to affect common law rights in marks acquired at any time. Thus many statutes establish the first use service mark but provide an opportunity for strict judicial interpretation to stifle its development.

The Trademark Act of 1946 provides inore guidance but expresses a general legislative purpose to afford the benefits of federal registration only to owners of trade syinbols whose trade symbol rights are secured by state or foreign law. Arguably, the service mark section of the Trademark Act of 1946 is controlled by this basic purpose with the result that service mark applicants whose symbols have not acquired the requisite source significance under state law may be demed registration privileges. However, to the extent the apphicant can point to a state statutory or common law policy recognizing rights in service inarks at first use, even though not fully developed in state decisions, the legislative purpose of the Act may be held by federal courts to be satisfied. If state courts follow the example of the Third Circuit in the American Plan $^{127}$ case, most applicants for federal service mark registration will be able to avoid the conceptual pitfall in the federal statute.

Preferably, Congress will recognize the need to offer substantive federal protection to all arbitrary source symbols used in commerce by

125. Present law requires not only that a mark owner affix his mark but that he affix it with a purpose to acquire mark rights and that he thereafter use it sufficiently continuously to justify a conclusion that the enterprise shows enough promise to warrant an official recognition of trademark rights. Cases occur where a court or agency declares that a particular use of a symbol did not qualify as a trademark use, because the firm did not actually communicate with consumers [In re Lyndale Farm, 186 F.2d 723 (C.C.P.A. 1951)] or communicated information about grade or quality rather thau source. Norwine Coffee Co. v. Chase \& Sanborn, 58 F.2d 430 (C.C.P.A. 1932).

126. See text accompanying notes 100-13 supra.

127. See text accompanying notes 84-89 supra. 
product firms and service firms as of the date of first use in communicating source significance to consumers and amend the Trademark Act accordingly. In so doing, Congress would complete the development begun long ago at common law in the clothier's case. 


\section{California Law Review}

\begin{tabular}{lll}
\hline \hline Vol. 58 & June 1970 & No. 4 \\
\hline \hline
\end{tabular}

\section{BOARD OF EDITORS}

\author{
Editor-in-Chief \\ JOSEPH T. KIEFER \\ Chief Managing Editor \\ ROBERT D. EVANS
}

Notes \& Comments

Kent SinClaIR, JR.

D. Rebecca SNow

Peter J. Aschentrenner

JAMES R. FARRAND

PAUL E. GILBERT

Paul W. GlenN

Michael L. MEYers

BRUCE S. Ross

Kent A. Russell

JAMES TOLEDANO

MERRICK JOHN BOBB

WiLliam M. ChamberLain

Diane D. Eames

ROBERT ERICSON

JUDITH G. KIEINBERG

GENE HARTER

DaVID M. Achterkirchen

ROBERT C. BARRETT

STEVEN A. BRICK

LAWRENCE R. BROWN

MARY Jo ChRISTENSEN

JoHn F. Davis

STEVEN M. DRUKER

HENRY C. EAMES, JR.

AUBAN ANN EISENHARDT

CharLes R. FarraR, JR.

\section{Articles}

Wirliam F. Cook

Steven Finell

Maria TANRENSON

Managing

DarVish $M$. Kordestani

Michael George Kozak

Book Reviews

J. Michael Brennan

MARY DUNLAP

Associate Editors

ELLYN A. HeRshman

JOHN E. MASON, JR.

RoBIn MEADOW

Dotglas alan Oglesby

LAWRENCE B. ORDOWER

RICHARD L. PARRISH

Second Year

JAMES C. FOWLER

HAROLD FRIEDMAN

Carol G. HaMMeTt

DAVID L. HAMMETT

JMMMIE HARRIS

ROBERT L. HARRIS

SPENCER R. KAITZ

DeNNIS S. KarJala

Sherla S. Kato

RICHARD MARCUS

ThOMAS M. MURRAY

Administrative Aide

SUSAN G. VeGA
Research

G. KIP EDWARDS

DAVID R. ANDREWS

Charles H. Hurd

Douglas M. LAURICE

ROBERT LEVY

Supreme Court Editor

GREGORY J. HoBBS, JR.

Executive Editor

WIIIIAM BILLINGSLEA, JR.

Richard L. Perez

Omar Petrona

Peter E. Sheehan

MARGARET SHERWOOd

Michael B. StMon

ROBERT D. STRATMORE

Carol Brdch Myers

Elaine T. Nelson

LYNN H. PASAHOW

REX PERschbacher

THOMAS B. ROSENBERG

ROBERT K. SCHEBELHUT

MARK HAROLD SHENFIELD

Susan J. Tamura

SCOTT R. WIILERT

STEPHEN ZAMORA 